\title{
PENGEMBANGAN SUMBER BELAJAR BERBASIS WEBLOG PADA MATERI MATA PELAJARAN GEOGRAFI KELAS XI SMA
}

\author{
Hervina $^{1}$, Nofrion ${ }^{2}$ \\ Program Studi Pendidikan Geografi \\ Fakultas Ilmu Sosial, Universitas Negeri Padang \\ Email: $\underline{\text { Hervina15@gmail.com }}$
}

\begin{abstract}
Abstrak
Penelitian ini bertujuan untuk mengembangkan sumber belajar berbasis weblog pada materi Mata pelajaran Geografi SMA kelas XI yang valid dan praktis digunakan dalam kegiatan pembelajaran. Jenis penelitian yang digunakan adalah penelitian dan pengembangan (Research and Development) menggunakan model ASSURE mengikuti standar KKNI level VI. Enam prosedur ASSURE adalah analisis peserta didik, merumuskan tujuan, memilih media, metode, dan materi, memanfaatkan material, peran serta peserta didik, dan evaluasi serta revisi. Instrumen yang digunakan adalah lembar uji validitas dan lembar angket kepraktisan. Hasil penelitian menunjukkan bahwa sumber belajar berbasis weblog bernilai valid dan praktis digunakan dalam kegiatan pembelajaran Geografi kelas XI SMA.
\end{abstract}

Kata kunci: pembelajaran Geografi, sumber belajar geografi, weblog Geografi

\section{Abstract}

The research is conducted in order to develope the valid and practical Geography learning resource weblog base of second years senior high school. This research was Research and Development $(R \& D)$ with used ASSURE base on KKNI standart level VI. There are six procedure of ASSURE, which are analyze learner, state objectivities, select methode, media, and materials, utilized technology, media, materials, require learner participation, and evaluate and revise. the research instruments used to collect data was a validation sheet and practicalities shet. The result of research showed that the development of learning resource weblog had valid and practical criteria.

Keywords:Geography learning, Geography learning resource, Geography weblogs

\footnotetext{
${ }^{1}$ Mahasiswa Program Studi Pendidikan Geografi untuk Wisuda Maret 2018

${ }^{2}$ Dosen Jurusan Geografi Fakultas Ilmu Sosial Universitas Negeri Padang, pembimbing Nofrion, M.Pd.
} 


\section{PENDAHULUAN}

Pembelajaran sebagai proses belajar bertujuan untuk mengembangkan kreatifitas berpikir dan meningkatkan pengetahuan peserta didik terhadap materi yang didukung oleh sumber belajar. Perkembangan teknologi dan ilmu pengetahuan menjadi tantangan dan dorongan bagi dunia pendidikan untuk melakukan upaya pembaruan dengan memanfaatkan hasil teknologi dalam pembelajaran.

Pembelajaran Geografi yang ideal menurut adalah pembelajaran yang membentuk dan mengembangkan empat aspek pada peserta didik. Keempat aspek tersebut adalah pengetahuan, keterampilan, sikap, dan perspektif geografi (Nofrion:2017). Untuk mencapai pembelajaran Geografi yang ideal ini, dibutuhkan dukungan dari sumber belajar. Keberadaan pendidik, peserta didik, interaksi antara pendidik dengan peserta didik, dan interaksi pendidik dan peserta didik dengan sumber belajar dalam suatu lingkungan belajar adalah suatu keharusan (Nofrion: 2012).

Menurut Association for Educational Communication and Technology (AECT) dalam Warsita (2008:209) sumber belajar adalah meliputi semua sumber, baik berupa data, barang atau benda yang dapat digunakan untuk memberi fasilitas (kemudahan) belajar bagi peserta didik.

Di dalam Permendikbud Nomor 22 Tahun 2016 tentang Standar Proses dijelaskan empat belas prinsip-prinsip dalam pembelajaran, dua di antaranya adalah; prinsip ke-2; dari guru sebagai satu-satunya sumber belajar menjadi menjadi belajar berbasis aneka sumber belajar, dan prinsip ke-13; pemanfaatan teknologi informasi dan komunikasi untuk meningkatkan efisiensi dan efekifitas pembelajaran. Jika dalam konteks pendidikan tradisional guru adalah sumber belajar yang dimiliki siswa, maka ditengah pesatnya perkembangan teknologi informasi dan komunikasi, guru bukanlah satu-satunya sumber belajar yang dimiliki siswa.

Salah satu sumber belajar yang dapat digunakan dalam proses pembelajaran adalah sumber belajar berbasis weblog. Weblog adalah jenis situs Web yang dikembangkan dan dikelola seseorang dengan menggunakan perangkat lunak (software) online atau platform host yang mudah digunakan, dengan ruang untuk menulis yang memberikan publik kesempatan untuk membaca dan memberikan umpan balik (Solomon dan Schrum, 2011:15).

Sumber belajar berbasis weblog merupakan sumber belajar yang disusun dan dikembangkan dengan memanfaatkan fasilitas internet secara positif. Sumber belajar berbasis blog tergolong dalam blog pendidikan yang biasanya ditulis oleh pelajar atau guru dengan konten mengenai pendidikan (Madcoms, 2010:6). Sumber belajar berbasis weblog memungkinkan siswa mengakses dan mempelajari materi 
dengan mudah. Sumber belajar berbasis weblog dapat mengatasi keterbatasan ruang dan waktu ketika melakukan kegiatan pembelajaran di kelas.

Secara umum, sumber belajar yang digunakan dalam kegiatan pembelajaran terbatas pada sumber belajar cetak berupa buku teks, dan guru sebagai sumber belajar utama. Padahal sekolah telah dilengkapi dengan fasilitas wifi dan labor komputer terkoneksi internet untuk mendukung proses pembelajaran. Tetapi fasilitas ini belum dimanfaatkan secara optimal.

Penggunaan sumber belajar berbasis blog dapat memaksimalkan penggunaan fasilitas yang disediakan sekolah karena sumber belajar ini memberikan beberapa keuntungan. Sumber belajar dapat diakses kapanpun dan dimanapun, hemat, interaktif, terbuka, mudah dan cepat (Politeknik Telkom, 2012).

\section{METODE PENELITIAN}

Jenis penelitian yang digunakan adalah penelitian pengembangan atau Research and Development. Penelitian pengembangan yang dilakukan mengikuti standar Kerangka Kualifikasi Nasional Indonesia (KKNI) level VI untuk sarjana S1 yaitu; mengaplikasikan, mengkaji, membuat desain, memanfaatkan IPTEKS dan menyelesaikan masalah. Produk yang dihasilkan pada penelitian ini adalah sumber belajar berbasis weblog pada materi pembelajaran Geografi SMA kelas XI.

Sumber belajar berbasis weblog ini dibuat berdasarkan prosedur ASSURE. Prosedur ASSURE terdiri dari 6 tahap yaitu (1) menganalisis peserta didik. (2) merumuskan tujuan, (3) memilih media, metode, dan materi, (4) memanfaatkan material, (5) peran serta peserta didik, dan (6) Mengevaluasi dan merevisi (Pribadi, 2011:112)

Produk yang telah didesain, divalidasi oleh ahli perangkat untuk validasi RPP dan ahli materi untuk validasi bahan ajar. Ahli perangkat terdiri dari satu orang dosen Geografi, dan ahli materi terdiri dari empat orang dose Geografi yang sudah berkompeten dibidangnya. Produk kemudian direvisi berdasarkan saran dan tanggapan yang diperoleh dari hasil validasi.

Langkah selanjutnya adalah melakukan ujicoba produk. Ujicoba produk dilakukan di SMA 1 Kamang Magek. Ujicoba dilakukan untuk mengetahui apakah sumber belajar berbasis weblog praktis digunakan dalam kegiatan pembelajaran.

Instrumen pengumpulan data yang digunakan dalam penelitian ini ada dua. Pertama, lembar uji validasi untuk uji validitas. Kedua, lembar angket kepraktisan untuk uji kepraktisan.

Teknik analisis data yang digunakan dalam penelitian ini adalah analisis validitas dan analisis kepraktisan. Data yang diperoleh dari uji 
validitas dan kepraktisan dianalisis menggunakan skala likert.

\section{HASIL DAN PEMBAHASAN}

\section{A. Hasil Penelitian}

Hasil penelitian ini terdiri dari tiga komponen. Pertama, proses pengembangan sumber belajar berbasis blog dengan model pengembangan ASSURE. Kedua, validitas sumber belajar yang dikembangkan. Ketiga, praktikalitas sumber belajar berbasis blog.

\section{Tahap Pengembangan}

Tahap pertama prosedur ASSURE adalah analisis peserta didik. Berdasarkan analisis peserta didik dari segi usia, umumnya siswa kelas XI IPS berusia rata-rata 16-17 tahun. Siswa kelas XI IPS sudah bisa mengoperasikan komputer dan internet dengan baik. Rata-rata siswa kelas XI juga memiliki gawai.

Masalah yang ditemukan dalam penelitian ini adalah peserta didik tidak memiliki buku cetak Geografi kurikulum 2013 revisi sebagai pegangan, sehingga ketika kegiatan belajar berlangsung, siswa hanya mengandalkan apa yang diberikan guru. Ketika siswa mencari materi pelajaran dari internet di labor komputer sekolah, banyak materi yang tidak ditemukan di internet. Kalaupun siswa menemukan materi di internet, materi yang tersedia tidak relevan dengan kurikulum 2013 edisi revisi. Berdasarkan pengakuan siswa, dalam kegiatan pembelajaran siswa menggunakan gawai tanpa sepengetahuan guru untuk bermain game atau online di media sosial, meskipun penggunaan gawai sudah dilarang selama proses pembelajaran berlangsung.

Berdasarkan temuan tersebut, maka sumber belajar berbasis weblog yang dikembangkan sesuai dengan kondisi peserta didik. Melalui sumber belajar berbasis weblog yang dikembangkan, siswa dapat mengakses materi pelajaran Georafi yang sesuai dengan Kurikulum 2013 edisi revisi melalui labor komputer di sekolah, atau melalui gawai masing-masing agar fasilitas yang diberikan orang tua dapat dimaanfaatkan secara maksimal untuk belajar.

Tahap kedua adalah state objectivies, menetapkan tujuan pembelajaran. Rumusan tujuan yang dirancang disesuaikan dengan siswa berdasarkan hasil analisis peserta didik. Tujuan pengembangan sumber belajar berbasis weblog secara umum ada dua, yaitu: 1) untuk memaksimalkan penggunaan labor komputer yang terkoneksi internet sebagai sarana kegiatan pembelajaran di sekolah; 2) untuk memfasilitasi peserta didik yang akrab dengan gawai, sehingga fasilitas yang diberikan oleh orang tua dapat dimaksimalkan pemanfaatannya dalam kegiatan pembelajaran, serta untuk memaksimalkan penggunaan labor komputer di sekolah. Sedangkan tujuan 
khusus disesuaikan dengan RPP yang akan dikembangkan.

Tahap ketiga adalah select methods, media, and materials, yaitu memilih media, metode pembelajaran, dan bahan ajar. Media yang digunakan adalah weblog dengan materi kelas XI SMA. Pemilihan media didasarkan pada kriteria yang dikemukakan oleh Rudi Susilana dan Riyana (2008: 70-72) yaitu:

(1) kesesuaian dengan tujuan, (2) kesesuaian dengan kondisi lingkungan, fasilitas pendukung, dan waktu yang tersedia.

Metode yang digunakan adalah metode demonstrasi untuk memperkenalkan blog kepada siswa kelas XI IPS SMA Negeri 1 Kamang Magek. Pada tahap ini, dilakukan pengembangan RPP berdasarkan silabus, kemudian dikembangkan bahan ajar, LKPD, dan power point. Kemudian perangkat yang telah dibuat akan divalidasi oleh ahli perangkat dan ahli materi.

Tahap keempat adalah utilize materials atau memanfaatkan bahan ajar.
Pada tahap ini, pengembangan dilakukan dengan memadukan teknologi internet, komputer, dan materi yang telah disusun. Sumber belajar yang dinilai telah valid akan diunggah ke dalam situs weblog yang telah dibuat.

Validasi oleh ahli media bertujuan utnuk mendapatkan informasi, kritik, dan saran agar sumber belajar berbasis weblog yang dikembangkan menjadi produk yang berkualitas secara tampilan, tipografi, pemograman, dan kelengkapan media.

Tahap kelima adalah requires learner participation, yaitu melibatkan siswa dalam kegiatan pembelajaran. Sumber belajar berbasis weblog dapat diakses peserta didik melalui perangkat komputer atau laptop atau ponsel pintar yang telah terkoneksi internet. Peserta didik juga dapat mengunduh sumber belajar yang telah diunggah pada halaman weblog. Tampilan halaman beranda weblog sumber belajar Geografi SMA kelas XI dapat dilihat pada gambar 1 berikut: 


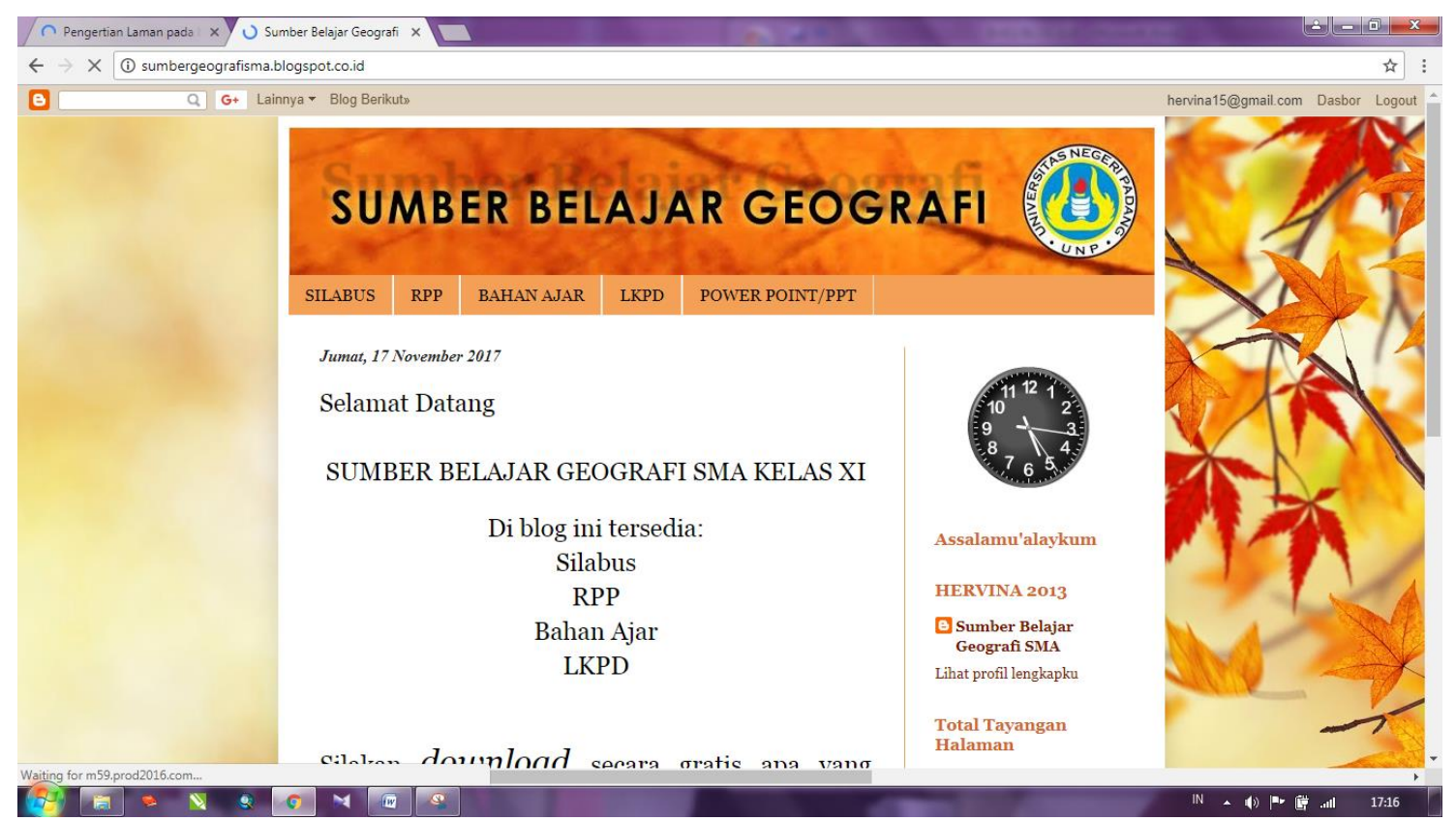

Gambar 1. Tampilan Beranda Sumber Belajar Berbasis Weblog

Sumber: sumbergeografisma.blogspot.co.id

Tahap lanjutan penelitian ini adalah keterlibatan peserta didik dalam penggunaan sumber belajar berbasis weblog. Pada tahap ini, peserta didik diperkenalkan pada sumber belajar berbasis weblog yang dikembangkan. peneliti mendemostrasikan weblog sumber belajar dan cara menggunakannya.

Setelah mengakses dan mempelajari materi yang disediakan dalam weblog, siswa sebagai praktikalis diminta melakukan penilaian terhadap sumber belajar berbasis weblog yang dikembangkan. Dalam hal ini, guru juga berperan sebagai praktikalis, pengguna sumber belajar berbasis weblog.

Tahap keenam adalah evaluate dan revise atau mengevaluasi dan merivisi sumber yang dikembangkan. Revisi dilakukan untuk mengetahui seberapa jauh sumber belajar berbasis weblog yang dikembangkan dapat mencapai tujuan yang telah ditetapkan sebelumnya.

Revisi ditentukan oleh komentar dan saran yang diberikan oleh praktikalis sebagai pengguna sumber belajar. Revisi yang dilakukan terhadap bahan ajar meliputi perbaikan tampilan dan tulisan. Perbaikan tampilan salah satunya dilakukan dengan menambahkan daya tarik weblog berupa gadget pada laman weblog. Perbaikan tulisan khususnya pada warna dan ukuran teks agar mudah dibaca.

Hasil uji validitas yang diperoleh dari lembar angket validitas sumber belajar terdiri dari tiga, yaitu uji 
kevalidan perangkat, uji kevalidan bahan ajar, dan uji kevalidan media.

Berdasarkan uji validitas RPP oleh ahli perangkat pada aspek kelayakan isi, kebahasaan, penyajian, dan kegrafisan, disimpulkan bahwa RPP termasuk dalam kriteria sangat valid. Deskripsi validasi RPP oleh ahli perangkat dapat dilihat pada gambar 2 berikut.

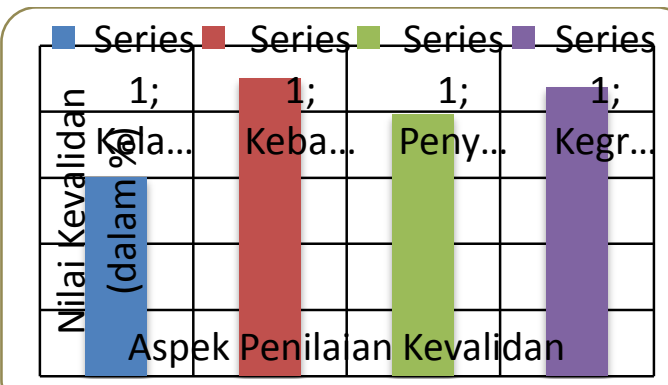

Gambar 2. Nilai Rata-Rata Validasi oleh Ahli Perangkat

RPP termasuk dalam kriteria sangat valid pada aspek kelayakan isi, kebahasaan, penyajian, dan kegrafisan. Nilai rata-rata kevalidan pada aspek kelayakan isi adalah $80 \%$ dengan kategori sangat valid. Nilai rata-rata kevalidan pada aspek kebahasaan 95\% dengan kategori sangat valid. RPP disusun menggunakan kaidah penulisan Bahasa Indonesia yang baik dan disesuaikan dengan PUEBI.

Nilai rata-rata kevalidan pada aspek penyajian adalah 89,6 \% dengan kategori sangat valid. Nilai rata-rata kegrafisan adalah 93,7\% dengan kategori sangat valid. Nilai keseluruhan analisis ahli perangkat adalah $89,4 \%$. Secara keseluruhan RPP berada pada kategori sangat valid.
Berdasarkan uji validitas bahan ajar oleh ahli materi pada aspek kelayakan isi, kebahasaan, penyajian, dan kegrafisan, disimpulkan bahwa bahan ajar termasuk dalam kriteria sangat valid. Deskripsi kevalidan bahan ajar oleh ahli materi dapat dilihat pada gambar 3.

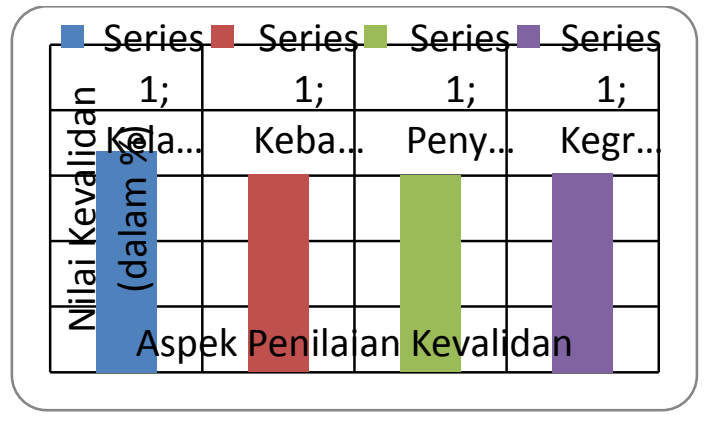

Gambar 3. Nilai Rata-Rata Validasi oleh Ahli Materi

Nilai kevalidan bahan ajar oleh ahli materi pada aspek kelayakan isi memperoleh nilai rata-rata $83,75 \%$. Nilai rata-rata pada aspek kebahasaan memperoleh nilai 80,2\% dengan kategori sangat valid. Nilai rata-rata aspek penyajian adalah $80 \%$ dengan kategori sangat valid. Nilai rata-rata kegrafisan adalah $80,35 \%$ dengan kategori sangat valid.

Berdasarkan penilaian yang dilakukan oleh ahli media, disimpulkan bahwa sumber belajar berbasis weblog sangat valid. Deskripsi kevalidan sumber belajar berbasis weblog oleh ahli media dapat dilihat pada gambar 4 . 


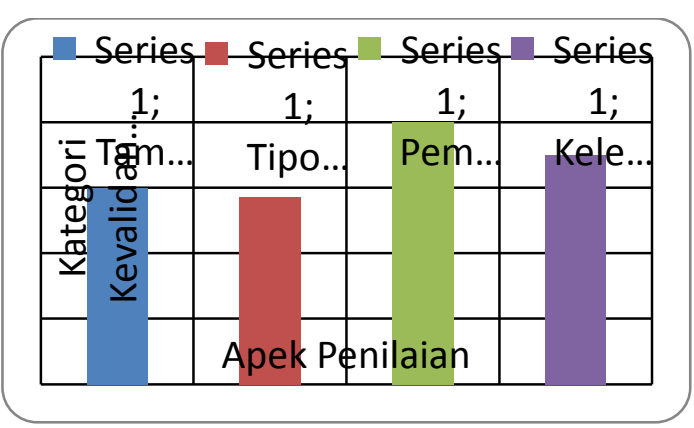

Gambar 4. Nilai Rata-Rata Validasi oleh Ahli Media

Nilai validitas rata-rata pada aspek tampilan adalah 80\%. Pada aspek tipografi, nilai kevalidan rata-rata adalah $78,6 \%$ dengan kategori praktis. Nilai validitas rata-rata pada aspek pemograman adalah $90 \%$ dengan kategori sangat valid. Nilai kevalidan rata-rata pada aspek kelengkapan media adalah $85 \%$ dengan kategori sangat valid.

Selama kegiatan validasi dilakukan, ada beberapa saran yang diberikan oleh validator untuk perbaikan terhadap bahan ajar. Saran yang diberikan validator berkaitan dengan kelengkapan materi, kelengkapan gambar dan peta, kesesuian ukuran gambar dalam bahan ajar dan sumber gambar yang digunakan.

Sumber belajar berbasis weblog direvisi sesuai dengan saran validator. Selanjutnya, dilakukan ujicoba di SMAN 1 Kamang Magek. Hasil uji kepraktisan diperoleh dari lembar instrumen prakatikalitas yang telah diisi oleh praktisi. Hasil uji kepraktisan terdiri dari dua, yaitu uji kepraktisan oleh guru, dan uji kepraktisan oleh siswa.
Berdasarkan uji kepraktisan terhadap sumber belajar Geografi berbasis weblog yang dilakukan oleh dua orang guru SMA Negeri 1 Kamang Magek, diperoleh kesimpulan bahwa sumber belajar berbasis weblog bernilai praktis. Deskripsi kepraktisan sumber belajar berbasis weblog oleh guru dapat dilihat pada gambar 5 .

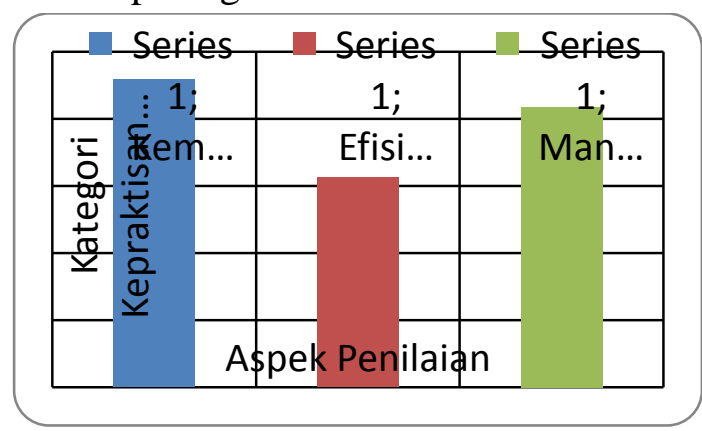

Gambar 5. Nilai Rata-Rata Kepraktisan Oleh Guru

Nilai kemudahan penggunaan memperoleh nilai akhir 95,8\% kategori sangat praktis. sumber belajar berbasis weblog mudah digunakan karena memiliki petunjuk penggunaan yang jelas dan tidak membutuhkan keahlian khusus untuk memanfaatkannya. Selain itu, sumber belajar berbasis weblog dapat digunakan berulang-ulang sesuai kebutuhan kapan saja dan dimana saja.

Aspek efisiensi waktu memperoleh nilai akhir 81,25\% dengan kategori sangat praktis. Siswa dapat menggunakan sumber belajar geografi berbasis weblog sesuai dengan kemampuan belajar masing-masing sehingga penggunaan waktu pembelajaran lebih efisien. Sumber belajar Geografi berbasis weblog 
memperoleh nilai akhir 91,7 \% pada aspek manfaat. Secara keseluruhan, sumber belajar berbasis weblog berdasarkan penilaian guru berada pada kategori sangat praktis dengan nilai akhir $92 \%$.

Uji kepraktisan siswa terdiri dari tiga aspek. Aspek pertama adalah kemudahan penggunaan, aspek kedua adalah efisiensi waktu, dan aspek manfaat. Hasil perolehan uji praktikalis oleh siswa kelas XI IPS SMA Negeri 1 Kamang Magek dapat dilihat pada gambar 6.

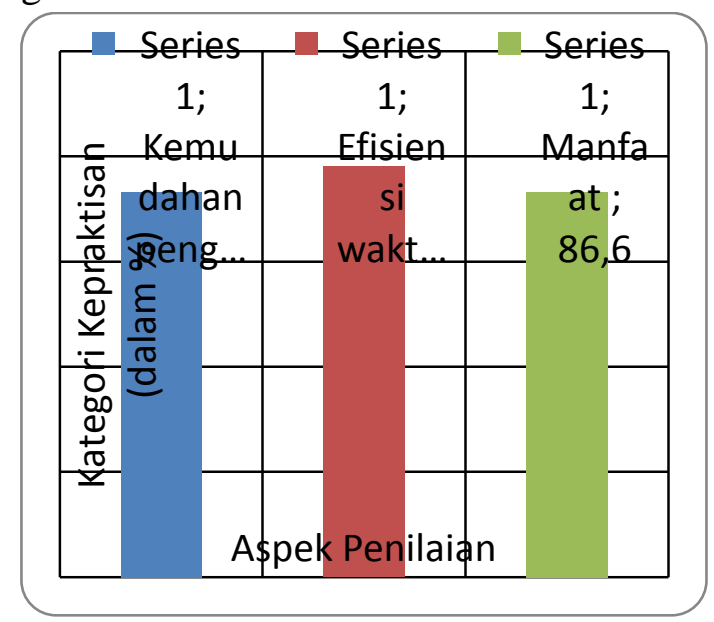

Gambar 6. Nilai Rata-Rata Kepraktisn oleh Siswa

Aspek kemudahan penggunaan memperoleh nilai praktikalis $86,6 \%$ dengan kategori sangat praktis. Berdasarkan penilaian siswa, sumber belajar berbasis weblog mudah digunakan karena memiliki petunjuk penggunaan yang jelas dan tidak membutuhkan keahlian khusus untuk memanfaatkannya. Siswa dapat mengakses dan menggunakan sumber belajar berbasis weblog kapan dan dimana saja.

Aspek efisiensi waktu memperoleh nilai praktikalis $89 \%$ dengan kategori sangat praktis. Siswa dapat menggunakan sumber belajar geografi berbasis weblog sesuai dengan kemampuan belajar masing-masing sehingga penggunaan waktu pembelajaran lebih efisien. Aspek manfaat memperoleh nilai praktikalis $86,6 \%$ dengan kategori sangat praktis. Secara keseluruhan, sumber belajar berbasis weblog berdasarkan penilaian siswa berada pada kategori sangat praktis dengan nilai $87 \%$.

\section{B. Pembahasan}

Berdasarkan penelitian yang telah dilakukan, maka diperoleh hasil penelitian berupa proses pengembangan ASSURE, validitas sumber belajar berbasis weblog, dan praktikalitas sumber belajar berbasis weblog. Hasil validasi terdiri dari hasil validasi oleh ahli perangkat, ahli materi, dan ahli media. Hasil uji kepraktisan terdiri dari uji kepraktisan oleh guru Geografi dan siswa sebagai pengguna sumber belajar berbasis weblog.

Hasil penelitian dan pengambangan ini adalah produk sumber belajar berbasis weblog pada materi pembelajaran Geografi kelas XI SMA. Penelitian ini mengacu pada tahapan penelitian dan pengembangan ASSURE. Proses pengembangan ASSURE terdiri dari 1) analyze learner, 
yaitu melakukan analisis karakter peserta didik. Pada tahap analisis peserta didik, ditemukan beberapa hal, yaitu a) belum optimalnya pemanfaatan komputer di labor sekolah, masih terbatas pada pelajaran tertentu, b) siswa sering menggunakan gawai dalam kegiatan pembelajaran untuk online atau bermain game, b) siswa tidak memiliki buku pegangan Geografi untuk belajar.

Tahap kedua adalah state objectivies, menetapkan tujuan pembelajaran. Rumusan tujuan yang dirancang disesuaikan dengan siswa berdasarkan hasil analisis peserta didik. Tujuan umumnya adalah untuk memfasilitasi peserta didik yang memiliki gawai agar dapat dimanfaatkan dalam kegiatan pembelajaran, serta untuk memaksimalkan penggunaan labor komputer di sekolah. Sedangkan tujuan khusus disesuaikan dengan RPP yang akan dikembangkan.

Tahap ketiga adalah select methods, media, and materials, yaitu memilih media, metode pembelajaran, dan bahan ajar. Media yang digunakan adalah weblog dengan materi kelas XI SMA. Metode yang digunakan adalah metode demonstrasi untuk memperkenalkan weblog kepada siswa kelas XI IPS SMA Negeri 1 Kamang Magek. Pada tahap ini, dilakukan pengembangan RPP berdasarkan silabus, kemudian dikembangkan bahan ajar, LKPD, dan power point. Kemudian perangkat yang telah dibuat akan direvisi oleh ahli perangkat dan ahli materi.
Tahap keempat adalah utilize materials atau memanfaatkan bahan ajar. Materi yang telah divalidasi dan dilakukan revisi sesuai saran ahli dapat diunggah ke weblog yang telah dibuat. Kemudian dilakukan validasi media oleh ahli media. Tahap kelima adalah requires learner participation,yaitu melibatkan siswa dalam kegiatan pembelajaran. Setelah sumber belajar berbasis weblog dinilai layak berdasarkan hasil penilaian, weblog akan diuji cobakan. Uji coba dilakukan di kelas XI IPS SMA Negeri 1 Kamang Magek. Dua orang guru geografi dan 25 orang siswa kelas XI IPS akan bertindak sebagai praktikalis. Langkah keenam dalah evaluate dan revise atau mengevaluasi dan merivisi sumber yang dikembangkan. Berdasakan saran dan komentar dari praktisi ini dilakukan evaluasi dan revisi produk.

Hasil validasi perangkat diperoleh dari instrumen validitas yang diisi oleh dosen Geografi. Hasil validasi menunjukkan bahwa RPP bernilai sangat valid digunakan dalam kegiatan pembelajaran Geografi. Sistematika pembuatan RPP didasarkan pada format penyusunan RPP dalam Permendikbud Standar Proses Nomor 22 Tahun 2016. RPP memuat komponen penyusunan RPP secara lengkap, RPP dikembangkan dari silabus untuk mengarahkan kegiatan pembelajaran peserta didik dalam upaya mencapai KD. RPP disusun berdasarkan KD yang akan dilaksanakan. Berdasarkan saran tanggapan dari ahli 
perangkat, maka dilakukan revisi terhadap RPP. Revisi yang dilakukan adalah penjabaran tujuan pembelajaran untuk setiap indikator, bukan hanya tujuan pembelajaran secara umum.

Hasil validasi bahan ajar dari ahli materi menunjukkan bahwa bahan ajar ajar bernilai sangat valid untuk digunakan dalam kegiatan pembelajaran Geografi karena telah memiliki kelayakan isi, kebahasaan, penyajian, dan kegrafisan yang baik. Hal ini sesuai dengan teori yang dinyatakan oleh Depdikbud (2008) bahwa kriteria penilaian validitas sebuah bahan ajar harus mencakup kelayakan isi, kebahasaan, penyajian, dan kegrafisan.

Hasil validasi dari ahli media menunjukkan bahwa sumber belajar berbasis weblog sangat valid digunakan dalam kegiatan pembelajaran Geografi karena telah memiliki tampilan, tipografi, pemograman, dan kelengkapan media yang baik dan menarik. Menurut Solomon dan Schrum (2010:1), menggunakan alat-alat yang dianggap menarik oleh siswa dapat membuat perbedaan dalam proses belajar dan membantu mempersiapkan diri di masa mendatang. Weblog merupakan media yang tepat sebagai sumber belajar karena mudah digunakan dan menggabungkan berbagai fitur seperti video, foto, grafik, peta, musik, dan perangkat audio (Huang dan Chen, 2013). Berdasarkan saran dan tanggapan validator, maka dilakukanlah revisi terhadap produk. Revisi yang dilakukan adalah dengan menambahkan gadget agar tampilan lebih menarik, dan memperbaiki warna tulisan pada link agar mudah dibaca.

Hasil uji kepraktisan diperoleh dari instrumen lembar uji kepraktisan menurut siswa dan guru terhadap sumber belajar berbasis weblog. Berdasarkan nilai yang diperoleh dari uji kepraktisan dapat disimpulkan bahwa sumber belajar berbasis weblog sangat praktis digunakan dalam proses pembelajaran Geografi. Sumber belajar ini praktis karena mudah untuk digunakan dan dipahami oleh siswa. Mudjijo dalam Husni (2014) mengemukakan bahwa kepraktisan menunjukkan pada tingkat kemudahan penggunaan, pelaksanaan dan penafsiran hasilnya.

\section{PENUTUP}

\section{A. Kesimpulan}

Penelitian pengembangan ini menghasilkan produk berupa sumber belajar berbasis weblog (diakses pada http://sumbergeografisma.blogspot.co.id) . Pengembangan sumber belajar berbasis weblog ini sesuai dengan prosedur pengembangan ASSURE, yaitu: 1) analyze learner (analisis peserta didik), 2) state objectivies (menetapkan tujuan pembelajaran), 3) select methods, media, and materials (memilih media, metode pembelajaran, dan bahan ajar) 4) utilize materials (memanfaatkan bahan ajar), 5) requires learner participation (peran serta peserta didik) 6) evaluate dan revise (evaluasi dan revisi). 
Hasil penelitian pengembangan yang telah dilakukan adalah tersusunnya sumber belajar berbasis weblog pada materi pembelajaran Geografi kelas XI SMA. Validasi sumber belajar berbasis weblog yang dihasilakan berada pada kriteria sangat valid, dengan rata-rata yang diperoleh $89,4 \%$ pada perangkat, $81,5 \%$ pada bahan ajar, dan 91,34\% pada media. Menu utama yang tersedia pada weblog ini adalah halaman utama weblog, RPP, bahan ajar, power point, dan LKPD, menu download.

Penggunaan sumber belajar berbasis weblog yang dikembangkan sangat praktis dengan nilai rata-rata praktikalitas $92 \%$ oleh guru, dan $86,6 \%$ oleh siswa. Sumber belajar berbasis weblog ini mudah digunakan karena memiliki petunjuk penggunaan yang jelas, materi yang diunggah lengkap, bahasa yang digunakan jelas dan mudah dipahami, serta beberapa fitur pendukung yang menjadikan weblog lebih interaktif.

\section{B. Saran}

Berdasarkan hasil penelitian pengembangan sumber belajar geografi berbasis weblog pada materi pembelajaran geografi kelas XI SMA, maka saran yang dianjurkan adalah guru dan siswa dapat menggunakan sumber belajar berbasis weblog sebagai salah satu variasi lain dari sumber belajar yang digunakan dalam proses pembelajaran Geografi di sekolah maupun secara mandiri sehingga dapat membantu mencapai kompetensi yang lebih baik.

\section{DAFTAR PUSTAKA}

Huang, T.-C, Chen, C-C. 2013. Animating Civic Education: Developing a Knowledge Navigation System using Blogging and Topic Map Technology. Journal (online). ISSN 1436-4522. IFETS.

Madcoms. 2010. Menggenggam Dunia dengan Internet. Yogyakarta : Penerbit Andi.

Nofrion. 2017. EXO OLO-Task Learneing Model: An Introduction to Hots-Oriented Learning Model Based On Lesson Study. Jurnal (online). ISSN 2222-288X. IISTE.

Nofrion. 2012. Peningkatan Aktivitas Belajar Siswa Melalui Penerapan Metode "Jumping Task"Pada Pembelajaran Geografi. Jurnal (online). ISSN: 2549-7057. Jurnal Unimed.

Permendikbud Nomor 22 Tahun 2016 tentang Standar Proses.

Politeknik Telkom. 2012. Pelatihan Penulisan Blog Wordpress. (online)

Pribadi, Benni A. 2011. Model Desain Sistem Pembelajaran. Jakarta: Dian Rakyat.

Solomon, Gwen. Lynne Schrum. 2011. Web 2.0 :Panduan bagi Para Pendidik, terj. Ririn Sjafriani. Jakarta: PT Indeks.

Sumbergeografisma.blogspot.co.id 
Warsita, Bambang. 2008. Teknologi Pembelajaran Landasan dan Aplikasinya. Jakarta: Rineka Cipta. 